\title{
Study on causes of infertility among males attending infertility clinic at a rural teaching hospital in Andhra Pradesh
}

\author{
K. Pushpalatha ${ }^{1}$, R Sudhakar ${ }^{2}$, G Raja Pramila ${ }^{3}$ \\ ${ }^{1}$ Dr. K. Pushpalatha, Associate Professor, Maheshwara Medical College, Chitkul (V), Near Isnapur X Roads, Patancheru, \\ Medak District, Telangana 502307, ${ }^{2}$ Dr R Sudhakar, Associate Professor Gitam Institute of Medical Sciences and \\ Research, Vizag, ${ }^{3}$ Dr G Raja Pramila, Professor, Gitam Medical College Rd, Rushikonda, Visakhapatnam, Andhra \\ Pradesh, India
}

Address for Correspondence: Dr. K. Pushpalatha, Associate Professor, Maheshwara Medical College, Sangareddy. Email id: resdoc555@gmail.com

\begin{abstract}
Introduction: The incidence of infertility is increasing in developed and developing counties due to various causes, out of these many are preventable. The paper outlines study conducted to find the impact of various causes in male. Methods: All patients who attended the infertility clinics of GEMS Medical College, Srikakulam, between March 2014 to February 2015 were included in the study. Results: Infertility was high among men aged 20-25 and 30-40 years with $62.07 \%$ and $62.96 \%$. Most common abnormality of infertility by microscopic study was found to be Pyospermia $(38.46 \%)$, followed by Oligozoospermia (16.92\%) and lowest abnormality is Hematospermia (3.08\%). Conclusion: Infertility is high in 20-25 and 30-40 age group. Pyospermia was the most common microscopic abnormality; Preventable causes $(87 \%)$ are commonest cause for infertility. Abnormality is found to be more than $50 \%$ among the patients.
\end{abstract}

Key words: Male, Infertility, Pyospermia, Microscopic study

\section{Introduction}

72.4 million couples globally experience fertility problems [1]. As per the WHO estimates 60-80 million couples worldwide currently suffer from infertility [2]. As per the $\mathrm{WHO}$, the overall prevalence of primary infertility ranges between $3.9 \%$ and $16.8 \%$ [2]. Also, the estimates of infertility vary widely among Indian states from 3.7\% in Uttar Pradesh, Himachal Pradesh, and Maharashtra, to 5\% in Andhra Pradesh, and 15\% in Kashmir [3-5].

In the developed countries and communities the birth rate is rapidly decreasing over years [6]. The incidence of infertility is increasing in developed and developing counties due to various causes, out of these many are preventable [7-9]. Now this phenomena has become quite common in India also. India's economic boom has started in 90s and resulted in change in lifestyle and behavioral aspects. More than $90 \%$ of male infertility

Manuscript received: $20^{\text {th }}$ November 2016

Reviewed: $30^{\text {th }}$ November 2016

Author Corrected: $08^{\text {th }}$ December 2016

Accepted for Publication: $15^{\text {th }}$ December 2016 cases are due to low sperm counts, poor sperm quality, or both. Male infertility refers to a male's inability to result pregnancy in a fertile female. "Male factor" infertility is seen as an alteration in sperm concentration and/or motility and/or morphology in at least one sample of two sperm analyzes collected 1 and 4 weeks apart [10].

Infertility and sub-fertility can be caused by various factors such as chromosomal and genetic disorders, physical and mental stress, obesity, malnutrition, smoking, drug abuse, cryptorchidism, Sexually Transmitted Diseases (STDs), contraceptive procedures, accessory gland infections, germ cell malignancies, and testicular cell calcification, disorders of ejaculation, varicocele, endocrine disruption and autoimmunity [1113]. Sperm abnormalities can be caused by wide range of factors like congenital birth defects, disease, chemical exposure and life style habits. These abnormalities either affect sperm count, movement or shape. 


\section{Research Article}

Categorization of Causes of infertility: The causes of the infertility are grouped as follows for the study. Physical Aspects: Lack of active exercises, Behavioral Patterns

Unhealthy Habits: Smoking and usage of recreational drugs. Over exercising

Food habits: Eating junk food frequently, excessive or frequent consumption of alcohol, which lead to obesity, as they impair hormonal levels adversely and affect the fertility.

Working Environment: Exposure to hazardous conditions such as working in pesticide factories, exposure to microwaves and noisy factors [14-16] also affect fertility.

Infections: prostatitis (inflammation in the prostate gland), orchitis (in the testicle), semino-vesculitis (in the glands that produce semen), or urethritis (in the urethra),

Unknown reasons: Genetic disorders, Cystic fibrosis, polycystic kidney disease.

Microscopic abnormalities- The abnormalities of infertility that are found in microscopic study can be grouped as follows.

Pyospermia: Pus cells in semen

Oligozoosmermia: Reduced sperm count

Hematosmermia: RBCs in semen

Oligoasthenozoosmermia: Reduced count and motility

Asthenozoosmermia: Reduced motility

Necrosmermia: Dead sperms in semen

Results

113 male patients aged 18 -55 have visited the lab for infertility test. The patients were requested to submit the semen in a clean container. After the collection, a slide was prepared for the microscopic examination of the semen. Out of 113,65 (57.2\%) men had infertility. Infertility was high among men aged 20-25 and 30-40 years with 62.07\% and 62.96\%. Lowest is observed in men below 20 years. (Table1)

Most common abnormality of infertility by microscopic study was found to be Pyospermia with $38.46 \%$, followed by Oligozoosmermia (16.92\%) and lowest abnormality is Hematospermia with 3.08\%. (Table 3) Later either telephonic or face to face interviews were conducted to find the reasons behind the abnormality. Abnormality was high among the people, who had Infections (17.58\%), unknown reasons (13.94\%), lack of physical activity $12.73 \%$ and unhealthy habits $12.73 \%$. The table 4 , shows controllable reasons amount to $>80 \%$, a primary cause of infertility.

\section{Table-1: Normal and Abnormal cases}

\begin{tabular}{|c|c|c|}
\hline Number of patients & Normal & abnormal \\
\hline 113 & 48 & 65 \\
\hline$\%$ of cases & $42.48 \%$ & $57.52 \%$ \\
\hline
\end{tabular}


Research Article

Table-2: Age-wise distribution of cases

\begin{tabular}{|l|c|c|c|}
\hline Age wise distributions & No of patients & Abnormal Cases & Abnormal Percentage \\
\hline Below 20 & 3 & 1 & $33.33 \%$ \\
\hline 20 to 25 & 29 & 18 & $62.07 \%$ \\
\hline 25 to 30 & 51 & 28 & $54.90 \%$ \\
\hline 30 to 40 & 27 & 17 & $62.96 \%$ \\
\hline Above 40 & 3 & 1 & $33.33 \%$ \\
\hline
\end{tabular}

Table-3: Age-wise Microscopic abnormalities

\begin{tabular}{|l|c|c|c|c|c|c|c|c|}
\hline $\begin{array}{l}\text { Age wise } \\
\text { distributions }\end{array}$ & $\begin{array}{c}\text { Pyospe } \\
\text { rmia }\end{array}$ & $\begin{array}{c}\text { Oligozoo } \\
\text { smermia }\end{array}$ & $\begin{array}{c}\text { Hemato } \\
\text { smermi } \\
\mathbf{a}\end{array}$ & $\begin{array}{c}\text { Oligoasthen } \\
\text { ozoosmermi } \\
\mathbf{a}\end{array}$ & $\begin{array}{c}\text { Asthenozoo } \\
\text { smermia }\end{array}$ & $\begin{array}{c}\text { Necros } \\
\text { mermia }\end{array}$ & $\begin{array}{c}\text { Azoosp } \\
\text { ermia }\end{array}$ & $\begin{array}{c}\text { Teratos } \\
\text { permia }\end{array}$ \\
\hline Below 20 & 1 & 0 & 0 & 0 & 0 & 0 & 0 & 0 \\
\hline 20 to 25 & 9 & 2 & 1 & 4 & 0 & 0 & 1 & 1 \\
\hline 25 to 30 & 9 & 6 & 1 & 2 & 4 & 1 & 2 & 3 \\
\hline 30 to 40 & 6 & 3 & 0 & 3 & 1 & 1 & 2 & 1 \\
\hline Above 40 & 0 & 0 & 0 & 0 & 0 & 0 & 1 & 0 \\
\hline total & 25 & 11 & 2 & 9 & 5 & 2 & 6 & 5 \\
\hline$\%$ & $38.46 \%$ & $16.92 \%$ & $3.08 \%$ & $13.85 \%$ & $7.69 \%$ & $3.08 \%$ & $9.23 \%$ & $7.69 \%$ \\
\hline
\end{tabular}

Table-4: Frequency of causes of infertility

\begin{tabular}{|c|c|c|c|c|c|c|c|c|c|c|}
\hline 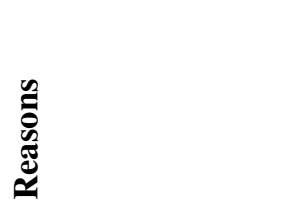 & 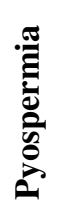 & 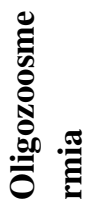 & 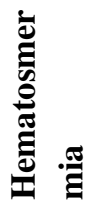 & 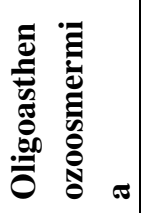 & 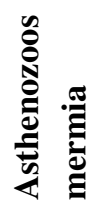 & 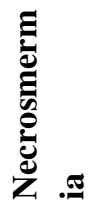 & 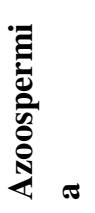 & 离 & 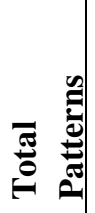 & 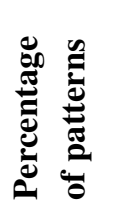 \\
\hline No of patients & 25 & 11 & 2 & 9 & 5 & 2 & 6 & 5 & 65 & \\
\hline Physical Aspects & 5 & 6 & 0 & 4 & 3 & 1 & 2 & 0 & 21 & $12.73 \%$ \\
\hline Behavioral Pattern & 5 & 6 & 0 & 0 & 2 & 1 & 2 & 2 & 18 & $10.91 \%$ \\
\hline Unhealthy Hobbits & 10 & 5 & 0 & 0 & 2 & 0 & 3 & 1 & 21 & $12.73 \%$ \\
\hline Over exercising & 2 & 4 & 1 & 3 & 1 & 0 & & 2 & 13 & $7.88 \%$ \\
\hline Food habits & 5 & 6 & 0 & 3 & 2 & 0 & 1 & 1 & 18 & $10.91 \%$ \\
\hline $\begin{array}{l}\text { Working } \\
\text { Environment }\end{array}$ & 2 & 1 & 1 & 3 & 1 & 0 & 1 & 0 & 9 & $5.45 \%$ \\
\hline $\begin{array}{ll}\text { Multiple } & \text { Sexual } \\
\text { Partners } & \\
\end{array}$ & 5 & 3 & 0 & 3 & 2 & 0 & 0 & 0 & 13 & $7.88 \%$ \\
\hline Infections & 20 & 5 & 1 & 2 & 1 & 0 & 0 & 0 & 29 & $17.58 \%$ \\
\hline Unknown reasons & 10 & 3 & 1 & 2 & 1 & 2 & 2 & 2 & 23 & $13.94 \%$ \\
\hline
\end{tabular}

\section{Discussion}

Reproduction is essential for the continuation of the genome of individuals and species including human. The desire of survival and continuation of the genome is strong enough that the human individuals fail to reproduce have poor social, mental and physical health. For the remedies of the condition, estimation of prevalence and factors are pre-requisite. The overall incidence of infertility over the last two decades varied between $8.97 \%$ to $14.63 \%$. Incidence of primary infertility had a higher incidence as compared to secondary infertility. Over the years it was proved that the incidence of infertility varied between 10-20\% [1720]. In a Cohort study conducted in Iraq, Razzak and Wall reported incidence of primary infertility as $77.20 \%$ 
and secondary infertility as $22.80 \%$ and Sinha et al of $65.83 \%$ and $34.17 \%$ respectively [21]. Our observations were compared to them of $57.2 \%$ primary infertility and $22 \%$ secondary infertility. When semen analysis reports of 113 cases were analysed it was evident that the most affected age group was $25-40$ years. This was similar to study conducted by H.A. A.L Turki et al 2015 [22].

Most common abnormality of infertility by microscopic study was found to be Pyospermia with $38.46 \%$, followed by Oligozoosmermia with $16.92 \%$. The prevalence of pyospermia was more among men in the age group 25- 30 years was $36 \%$ and $24 \%$ among 35 $40 y r s$ age group.

Abnormality was high among the people who have Infections with $17.58 \%$, unknown reasons with $13.94 \%$, lack of physical activity $12.73 \%$ and unhealthy habits $12.73 \%$. Durphy et al, (1991) suggested that chronic alcoholism can cause testicular atrophy leading to oligospermia or azoospermia and also cause ejaculatory dysfunction. In the present study the relationship between alcohol consumption and abnormalities of semen was evident and supports the findings of the above authors [23-26].

In the present study the significant relationship of alcoholism and cigarette smoking to abnormalities of semen was appreciated, but still this can be under reporting of the smoking habits because as this can be other way round as the patients are generally not comfortable about giving history of any addiction even though present.

With the advancing age a decline in testosterone and increase in gonadotrophins are associated with a decrease in sperm production and number of normal sperm [26].

\section{Conclusions}

- Infertility is high in 20-25 and 30-40 age groups. Pyospermia is found be higher in percentage. Preventable causes $(87 \%)$ are commonest cause for infertility. Abnormality is found to be more than $50 \%$ among the patients.

- Optimal of age of marriage, refraining from addictions, timely medical assistance can help the couples to have successful pregnancy.

- Due to diverse environmental, nutritional and socioeconomic factors and climate conditions, it is important to assess the semen quality in different parts of the country.
Acknowledgements- We would like to acknowledge the staff of department of Pathology for extending their support and cooperation to carry out the study.

Funding: Nil, Conflict of interest: None initiated, Permission from IRB: Yes

\section{References}

1. Boivin J, Bunting L, Collins JA, Nygren KG. International estimates of infertility prevalence and treatment-seeking: Potential need and demand for infertility medical care. Hum Reprod. 2007 Jun;22(6):1506-12. Epub 2007 Mar 21.

2. Calverton, Maryland, USA: ORC Macro and the World Health Organization; 2004. World Health Organization. Infecundity, Infertility, and Childlessness in Developing Countries. DHS Comparative Reports No 9.

3. Talwar PP, Go OP, Murali IN. New Delhi: National Institute of Health and Family Welfare and Indian Council of Medical Research; 1986. Prevalence of infertility in different population groups in India and its determinants. Statistics and Demography.

4. Unisa S. Childlessness in Andhra Pradesh, India: Treatment-seeking and consequences. Reprod Health Matters. 1999;7:54-64.

5. Zargar AH, Wani AI, Masoodi SR, Laway BA, Salahuddin M. Epidemiologic and etiologic aspects of primary infertility in the Kashmir region of India. Fertil Steril. 1997 Oct; 68(4):637-43.

6. E. Carlsen, A. Giwercman, N. Keiding, and N. E. Skakkebaek. Evidence for decreasing quality of semen during past 50 years. British Medical Journal, 1992; 305(6854): 609-613

7. T. F. Sandeman. The effects of $x$ irradiation on male human fertility. British Journal of Radiology,1966; 39 (468):901-907.

8. Brake and W. Krause. Decreasing quality of semen. British Medical Journal, 1992; 305(6867):1498.

9. W. Zorgniotti, A. I. Sealfon, and A. Toth. Further clinical experience with testis hypothermia for

infertility due to poor semen. Urology, 1982; 19(6):636-40. 


\section{Research Article}

10. 4th ed. Cambridge: Cambridge University Press; 1999. World Health Organization. WHO Laboratory Manual for the Examination of Human Semen and Semen-Cervical Mucus Interaction; pp. 1-86.

11. Cocuzza M, Sikka SC, Athayde KS, Agarwal A. Clinical relevance of oxidative stress and sperm chromatin damage in male infertility: an evidence based analysis. Int Braz J Urol. 2007; 33: 603-21.

12. Olayemi FO. A review on some causes of male infertility. Afri J Biotechnol. 2010; 9: 2834-2842.

13. Olesen IA, Sonne SB, Hoei-Hansen CE, Rajpert-De Meyts E, Skakkebaek NE. Environment, testicular dysgenesis and carcinoma in situ testis. Best Pract Res Clin Endocrinol Metab. 2007; 21: 462-78.

14. L. Carosi and F. Calabrò. Fertility in couples working in noisy factories. Folia Medica,1968; 51(4): 264-8.

15. D. Whorton, R. M. Krauss, S. Marshall, and T. Milby. Infertility in male pesticide workers. The Lancet, 1977;2 (8051):1259-1261.

16. Lancranjan I, M. Maicanescu, E. Rafaila, I. Klepsch, and H. I. Popescu. Gonadic function in workmen with long term exposure to microwaves. Health Physics, 1975;29( 3):381-3.

17. Sherrod R.A. Understanding the emotional aspects of infertility: implications for nursing practice. J. Psychosoc Nurs Ment Health Serv. 2004; 42 (3): 40-7.

18. Speroff L. and Firtz M.A. Clinical Gynaecological and Infertility, 7th Edition, Lippincott William \&
Wilkins, London, 2005; 1135-1173.

19. Burney R.O., Schust D.J., Yao M.W.M. Infertility:In Berek \& Novak's Gynaecology, 14th edition, Edi Berek JS, Lippincott William \& Wilkins London, 2007; 1185-1275.

20. Safarinejad, M. R. Infertility among couples in a population-based study in Iran: prevalence and associated risk factors. Int J Androl. 2008 Jun;31(3):303-14. Epub 2007 May 7.

21. Razzak A.H., Wais S.A. The infertile couple: A Cohort study in Duhok, Iraq. East Mediterr Health J,2002;8 (2-3): 234-8.

22. Haifa A. Al-Turki. Prevalence of primary and secondary infertility from tertiary center in eastern Saudi Arabia. Middle East Fertility Society Journal (2015); 20: 237-240.

23. Jensen T.K., Hjollund N.H.I., Henriksen T.B. et al. Does moderate alcohol consumption affect fertility ? Follow up study among couples planning first pregnancy. Br Med J,1988; 317: 505-10.

24. Durphy B.C, Barratt U.R., Von Tongelen B.P., Cooke I.D. Male cigarette smoking and fecundity in couples attending and infertility clinic. Andrologia, 1991; 23: 223-25.

25. Dhaliwal L.K., Gupta K.R., Majumdar S. The need for clinical evaluation and semen analysis of infertile men. Int J Fertil Womens Med. 2000 MayJun;45(3):232-5.

26. Kalyani R, Basavaraj PB, Kumar ML. Factors influencing quality of semen: a two year prospective study. Indian J Pathol Microbiol. 2007 Oct;50(4):890-5.

\section{How to cite this article?}

K. Pushpalatha, R Sudhakar, G Raja Pramila. Study on causes of infertility among males attending infertility clinic at a rural teaching hospital in Andhra Pradesh. Trop J Path Micro 2016;2(3):201-205.doi: 10.17511/jopm.2016.i03.20 